\title{
The impact of soil quality on cocoa yield in Nigeria
}

\author{
O. A. Amusan $^{1} \&$ F. O. Amusan ${ }^{2}$ \\ ${ }^{1}$ University of Bonn, Institute of Agriculture, \\ Water Engineering and Land Improvement, Bonn, Germany \\ ${ }^{2}$ Alcon Labs, UK
}

\begin{abstract}
The Southwestern region of Nigeria is the largest administrative region in Nigeria; it occupies about 30 percent of Nigeria and has an estimated population of about 40 million. Over 50 percent of the area is categorised as rural areas of which about 90 percent of the people depend on farming for their livelihood. Over 90 percent of Nigerian cash crop cocoa is produced in the cocoa belt of the Southwestern region, but both cash and food crops have consistently declined in the last few years. This phenomenon constitutes a threat to food security and calls for efforts to explain the downward trend and make recommendations for improvement. The objectives of this study were to evaluate the soils of some areas in Southwestern Nigeria for cocoa on the one hand, and identify factors affecting cocoa yield on the other. A novel technique that combines soil survey with socio-economic analyses was adopted. Socio-economic surveys covered resource quality and constraints to agricultural production, whereas soil sampling and analyses were carried out to assess the contribution of soil to yield. Three locations having similar agro-ecological features were selected, namely Ibadan, Ife and Akure. Cocoa farmers were randomly selected and interviewed on their farms using standardised questionnaires to elicit information on factors affecting crop yield. Relationships between cocoa yield and variables presumed to influence yield were determined using linear multiple regressions. Soil organic C, Age of farm soil, and ECEC were identified as the major constraints to yield. Other variables are related to biophysical and management factors. It is recommended that emphasis should be placed on soil management techniques that conserve organic matter and enhance the nutrient and water holding capacity of the soils. Policies that would enhance sustainability of agricultural land use and crop marketing are also required.
\end{abstract}

Keywords: cocoa yield, food security, land use, linear multiple regressions, soil organic $C$, soil quality. 


\section{Background and aim of the study}

The main soil factor affecting cocoa in Nigerian conditions is the clay content. This is important chiefly because a relatively high amount of clay in the soil gives it a fairly high capacity for retaining moisture, which remains available to the trees during the dry season. Soils in Southwestern Nigeria exhibit varying degrees of fertility. They are derived from hard crystalline rocks of the "Basement Complex" (gneisses, granites, schists, quartzites, and amphibolites), which have been eroded in varying degrees in different parts of the main cocoa belt. Fertile soils are found next to areas with poor soils and contiguous tracts of fertile cocoa soil are rare. Pockets of fertile soils can be found around Ife, Ibadan and Akure (Figure 1).
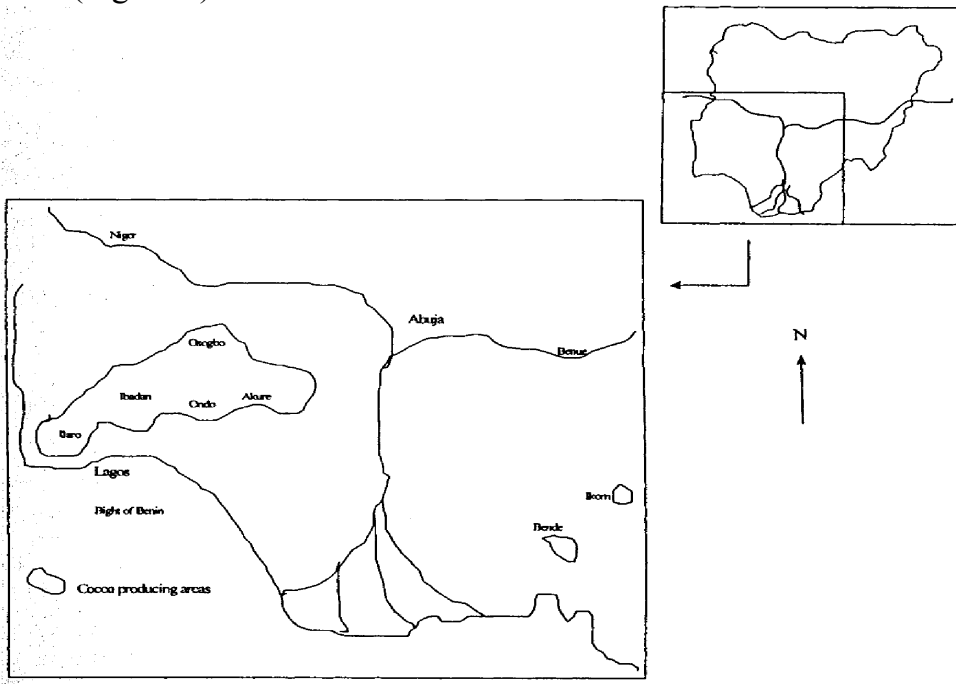

Figure 1: $\quad$ Map of the cocoa growing regions of Nigeria.

Cocoa grows best in soils with the following properties (Rehm and Epsig [1]):

1. A dark, grey brown, crumby humid surface layer $3.5-7.5 \mathrm{~cm}$ in thickness consisting of medium texture and free from coarse sand, grit or small gravel.

2. About $30 \mathrm{~cm}$ of medium-textured earth, brown or reddish-brown in colour.

3. A layer of friable red clay $60-90 \mathrm{~cm}$ in thickness

4. A layer of friable clay mottled whitish, orange, red and pale yellow, and $60-90 \mathrm{~cm}$ thick which grades into

5. Rotten, disintegrated rock, preferably of a granite nature or derived from dark-coloured igneous or volcanic material.

Cocoa-growing year, distinguished from cocoa-marketing year begins when moist air (the Equatorial Maritime air mass) sweeps in from the coast at the end 
of April or the beginning of May. From May to July and in September and October, rainfall averages at least $150 \mathrm{~mm}$ per month in nearly all cocoa-growing areas. The "little dry season" in August when the climate remains humid but rainfall is much less is characteristic of Southwestern Nigeria. If it is unduly long or dry, the cocoa crop may suffer severely. The crop may also suffer severely if the rains between July and October when the pods are ripening are unduly heavy. The northern limit of cocoa belt is marked partly by the line where rainfall approaches the lower limit of $1100 \mathrm{~mm} /$ year and partly, in the area of Ondo provinces where the rainfall is well above that limit. In this zone the influence of the dry Harmattan wind in the months from December to March is very strong and cocoa, which cannot stand long drought, seems unable to survive. Temperatures are lowest and relative humidity highest in the rainy months (the growing season) and plant growth is then very rapid. In the dry season, temperatures are high during the day and relative humidity falls very low during the afternoons. Conditions are then unfavourable to growth. The period during which even some of the hardiest crops cannot be successfully planted without constant watering is rather over three months in most of the main cocoa belt. Even at the highest elevations in the cocoa-growing areas temperature never fall so low as to be adverse to growth. Farmers therefore face replanting problems in old cocoa farms and high seedling failure in new plantings in marginal soils. This situation is affecting the future planting plans of cocoa farmers in Oyo, Ogun and Ondo States of Southwestern Nigeria. Although contiguous land masses suitable for cocoa growing exist outside the main cocoa belt (particularly in Ikom and Baissa of South-eastern Nigeria), the exceptional productivity arising from the fertile soil conditions has been eroded by the high incidence of Phytophthora (black pod) disease due to high rainfall. The disease is more prevalent in the high rainfall areas of the Southeastern state of Cross River than in the relatively drier cocoa areas of Southwestern Nigeria. This study is aimed at assessing the impact of soil quality on Cocoa yield in the study areas in Southwestern Nigeria. The specific objectives include:

1. To evaluate the soils of some areas in South-western Nigeria for cocoa

2. To identify factors affecting cocoa yield

3. To determine the biophysical and socio-economic constraints to quality cocoa production

\section{Methodology}

\subsection{Data set}

The analysis presented in this paper is based on primary data, which were collected by surveys of farm households, extensionists, farm mangers, etc. The Cocoa farm household samples (classified by farm size) were selected from three locations having similar agro-ecological features, namely Ibadan, Ife and Akure. The primary data from the socio-economic survey were used to elicit information on farm-farmers' characteristics vis-à-vis constraints to cocoa. Soil sampling and analysis were carried out to examine the role of soil properties in crop yield. 
Socio-economic and soil data were thereafter integrated to study their influence on crop yield.

\subsection{Socioeconomic survey}

A survey was carried out among cocoa growers in South-western Nigeria in the year 2002. Three locations having similar agro-ecological features were selected, namely Ibadan, Ife and Akure. Thirty cocoa farmers were randomly selected and interviewed on their farms using standardised questionnaires. Farmers interviewed in Ibadan belonged to three different groups of cooperative societies or farmers' organisation. The farmers interviewed at Ife and Akure belonged to the respective cooperative multipurpose unions (CPMU) in these towns. These cooperatives are profit -making organisations, however, they offer more than just marketing services for their members. Access to the farmers and their farmlands was obtained under the auspices of the Association of Nigerian Cooperative Exporters Limited (ANCE) and ongoing Project for Improvement of Cocoa Marketing and Trade in Nigeria (ICMT) sponsored by the International Cocoa Organisation (ICCO). While cocoa farmers in Ife and Akure are fully integrated into the ICMT project, the cocoa farmers in Ibadan are non-participants. The selection along the line of participation or non-participation on the project moreover enabled the evaluation of the project's overall influence on cocoa yield. The interview comprised of qualitative and quantitative components, covering aspects of agronomic activities, resource quality and availability, problems perceived and objectives set both at individual and cooperative levels. Additional information was collected in key-persons interviews from cocoa exporters, cocoa processors, cocoa researchers and representatives of governmental and non-governmental institutions. Official statistics and other secondary data served as background information.

\subsection{Soil sampling and analyses}

Biophysical data was obtained by analysis of soil samples taken from cocoa farms. Soils were analysed for chemical analyses. The soils were analysed for basic cations (determined in $1 \mathrm{~N} \mathrm{NH}_{4} \mathrm{OAc}$ ), total $\mathrm{N}$ (Kjedahl method), available $\mathrm{P}$ (Bray P method) organic C (Walkey-Black wet oxidation method) and pH (0.1M $\left.\mathrm{CaCl}_{2}\right)$.

\section{Results and discussion}

\subsection{Soil properties, land use history and crop yield}

The topography of the land at all study farms ranges from flat to gentle slope $(2-8 \%)$. Soil analyses (Tables 1and 2) showed that the soils are fairly high in total $\mathrm{N}($ mean $=0.20 \%)$, organic $\mathrm{C}($ mean $=1.89 \%)$, available $\mathrm{P}($ mean $=3.19$ ppm), but low in $\mathrm{Na}$. The $\mathrm{pH}$ is close to neutral (mean 6.5). In terms of variability, $\mathrm{pH}$ is the least variable $(\mathrm{cv}=7 \%)$ while available $\mathrm{P}$ is the most variable property $(\mathrm{cv}=69 \%)$. Statistics of soil properties at the sampled 
locations are presented in Tables 5 and 6 . Soil $\mathrm{pH}$ is the least variable across locations $(\mathrm{CV}=3-9 \%)$. Highest CV (100\%) among Ibadan soils occur for EA, while the highest $\mathrm{CV}$ of $119 \%$ occur for $\mathrm{P}$ for Ife soils while $\mathrm{Ca}$ and $\mathrm{K}$ manifests the most variable soil property amongst Akure soils $(\mathrm{C}=55 \%)$. This suggests that cations are the most variable properties among Akure soils. Test of mean differences show that none of the properties are significant across locations $(\mathrm{p}>0.05)$. This is because the soils have developed from similar soil parent materials derived from Precambrian rocks.

Table 1: General Statistics of soil properties $(\mathrm{N}=16)$. $(\mathrm{EA}=$ Exchangeable Acidity, $\mathrm{ECEC}=$ Effective cation exchange capacity.)

\begin{tabular}{|l|l|l|l|l|l|l|l|l|l|l|}
\hline & $\begin{array}{c}\mathrm{Ca} \\
(\mathrm{cmol} \\
/ \mathrm{kg})\end{array}$ & $\begin{array}{c}\mathrm{Mg} \\
(\mathrm{cmol} \\
/ \mathrm{kg})\end{array}$ & $\begin{array}{c}\mathrm{Na} \\
(\mathrm{cmol} \\
/ \mathrm{kg})\end{array}$ & $\begin{array}{c}\mathrm{K} \\
(\mathrm{cmol} \\
/ \mathrm{kg})\end{array}$ & $\begin{array}{c}\mathrm{EA}^{\mathrm{a}} \\
(\mathrm{cmol} \\
/ \mathrm{kg})\end{array}$ & $\begin{array}{c}\mathrm{ECEC}^{\mathrm{a}} \\
(\mathrm{cmol} \\
/ \mathrm{kg})\end{array}$ & $\begin{array}{c}\text { Total } \\
\mathrm{N} \\
(\%)\end{array}$ & $\begin{array}{c}\text { Availabl } \\
-\mathrm{e} \mathrm{P} \\
(\mathrm{ppm})\end{array}$ & $\begin{array}{c}\text { Orga- } \\
\text { nic C } \\
(\%)\end{array}$ & $\mathrm{pH}$ \\
\hline Mean & 4.34 & 1.11 & 0.07 & 0.38 & 0.02 & 5.90 & 0.20 & 3.19 & 1.89 & 6.46 \\
\hline Std & 2.08 & 0.48 & 0.02 & 0.21 & 0.02 & 2.55 & 0.05 & 2.19 & 0.61 & 0.44 \\
\hline $\mathrm{Cv}(\%)$ & 48 & 43 & 29 & 25 & 100 & 43 & 27 & 69 & 32 & 7 \\
\hline $\min$ & 1.49 & 0.30 & 0.04 & 0.06 & 0.00 & 2.15 & 0.14 & 0.99 & 1.16 & 5.70 \\
\hline $\max$ & 7.51 & 1.22 & 0.10 & 0.76 & 0.07 & 9.77 & 0.33 & 7.05 & 3.33 & 7.30 \\
\hline
\end{tabular}

\subsection{Relationship between land use history and crop yield}

Yields obtained differ depending on the variety of cocoa planted, age of the trees and farm maintenance. Higher yield was observed on farms planted predominantly with Amazon cocoa in comparison with those planted with Amelonado. Older farms have lesser yield than younger farms and farms are better maintained in regards to cultural operations were more productive. Table 18 presents the yield recorded on the farms during the 2001/02 cocoa seasons.

Table 2: $\quad$ Location statistics of soil properties $(\mathrm{N}=16)$.

\begin{tabular}{|c|c|c|c|c|c|c|c|c|c|c|c|c|}
\hline Location & $\begin{array}{c}\text { No of } \\
\text { samples }\end{array}$ & Statistics & $\mathrm{Ca}$ & $\mathrm{Mg}$ & $\mathrm{Na}$ & $\mathrm{K}$ & EA & ECEC & $\mathrm{N}$ & $P$ & Org.C & $\mathrm{pH}$ \\
\hline \multirow[t]{3}{*}{ Ibadan } & \multirow[t]{3}{*}{8} & Mean & 4.46 & 1.09 & 0.07 & 0.33 & 0.02 & 5.96 & 0.19 & 3.48 & 1.84 & 6.45 \\
\hline & & Std. dev & 2.06 & 0.44 & 0.02 & 0.23 & 0.02 & 2.39 & 0.05 & 2.53 & 0.57 & \begin{tabular}{|l|}
0.49 \\
\end{tabular} \\
\hline & & CV (\%) & 46 & 40 & 29 & 70 & 100 & 40 & 26 & 73 & 31 & \\
\hline \multirow[t]{3}{*}{ Ife } & \multirow[t]{3}{*}{4} & Mean & 3.89 & 0.97 & 0.06 & 0.42 & 0.02 & 5.36 & 0.21 & 5.5 & 2.11 & 6.56 \\
\hline & & Std. dev & 2.37 & 0.47 & 0.01 & \begin{tabular}{|l|}
0.12 \\
\end{tabular} & 0.01 & 2.74 & 0.08 & 6.56 & 0.88 & \begin{tabular}{|l|}
0.57 \\
\end{tabular} \\
\hline & & CV (\%) & 61 & 48 & 17 & 29 & 50 & 51 & 38 & 119 & 42 & \\
\hline \multirow[t]{3}{*}{ Akure } & \multirow[t]{3}{*}{4} & Mean & 4.73 & 1.31 & 0.08 & \begin{tabular}{|l|}
0.44 \\
\end{tabular} & 0.02 & 6.58 & 0.2 & 2.33 & 1.79 & 6.38 \\
\hline & & Std. dev & 2.61 & 0.64 & 0.02 & 0.24 & 0.01 & 3.44 & 0.04 & 0.93 & 0.45 & 0.22 \\
\hline & & CV (\%) & 55 & 49 & 25 & 55 & 50 & 52 & 20 & 40 & 25 & \\
\hline
\end{tabular}


Table 3: $\quad$ Yield statistics (kg/ha) on surveyed farms in the 2001/02 season.

\begin{tabular}{|l|l|l|l|l|}
\hline Location & No of farmers & Mean & Std. Deviation & CV (\%) \\
\hline Ibadan & 10 & 245 & 86 & 35 \\
\hline Ife & 10 & 347 & 166 & 48 \\
\hline Akure & 10 & 434 & 189 & 44 \\
\hline
\end{tabular}

Table 3 shows that average yield per hectare is highest in Akure and lowest in Ibadan. However Ife has the highest variability in yield. Mean yield among the sampled locations and coefficient of variation may largely reflect variability in management practices. Test of mean differences in yield at the locations is presented in Table 4.

Table 4: $\quad$ Least Significant Difference (LSD) test of yields.

\begin{tabular}{|l|l|l|l|}
\hline Location (1) & Location (2) & $\begin{array}{l}\text { Difference in mean yield } \\
\text { (Location 1-Location2) in } \\
\mathrm{kg} / \mathrm{ha}\end{array}$ & $\begin{array}{l}\text { Significant } \\
\text { Probability }\end{array}$ \\
\hline Ife & Ibadan & 102 & 0.15 \\
\hline Akure & Ibadan & 189 & $0.01 * *$ \\
\hline Akure & Ife & 87 & 0.22 \\
\hline
\end{tabular}

Table 4 shows that yield differences in Ibadan and Akure are highly significant $(\mathrm{p}<0.01)$, while yield differences at other pairs of locations are not significant $(\mathrm{p}>0.05)$. Ife and Akure farmers participate in the on-going ICMT project of the International Cocoa Organisation (ICCO) and therefore benefit from the expertise knowledge received at the farm management training sessions.

Statistical relationship between land use history and crop yield were studied in terms of recorded yield, and three other variables: age of farm, proportion of dormant trees, and proportion of trees replaced. Figure 2 shows that yield of cocoa generally increases with age of farm up to 35 years, and then declines. Age of trees explains $29 \%$ of variability in cocoa yield. This phenomenon may be related to the physiology of the crop, crop varieties and the fact that the input management strategy in terms of fertilizer application is generally low. Yield decreases with the proportion of dormant trees on farmers' field (Figure 3). Highest yields $(650-750 \mathrm{~kg} / \mathrm{ha})$ were obtained in fields with no dormant trees. As dormancy is a function of several factors such as age, disease and pest attack etc, the need for proper control of diseases and succession planting cannot be overemphasised. Dormant trees explain $81 \%$ of variability in cocoa yield. Figure 4 shows that yield of cocoa is strongly related to the proportion of replaced trees. This management option is particularly appealing to farmers given the fact that the application of farm inputs like fertilizers and pesticides is generally low. Proportion of replaced trees explains $89 \%$ of variability in cocoa yield.

Figure 5 shows that the tendency of cocoa yield to be low at extreme values of soil organic $\mathrm{C}$ (that is, organic $\mathrm{C}$ below $1.5 \%$ and above $2.5 \%$ ). The same observation holds for total $\mathrm{N}$ where yields are observed to be low for $\mathrm{N}$ values 
below $0.2 \%$ and above $0.25 \%$ (Figure 6 ). This result suggests that accumulation of organic materials in the soil is not necessarily favourable to the growth of cocoa. Figure 7 also suggests that $\mathrm{pH}$ below 6.0 and above 6.5 adversely affects yield. Yield is maximum at about a $\mathrm{pH}$ of 6.3 and attempt should be made to maintain soil $\mathrm{pH}$ around this level.

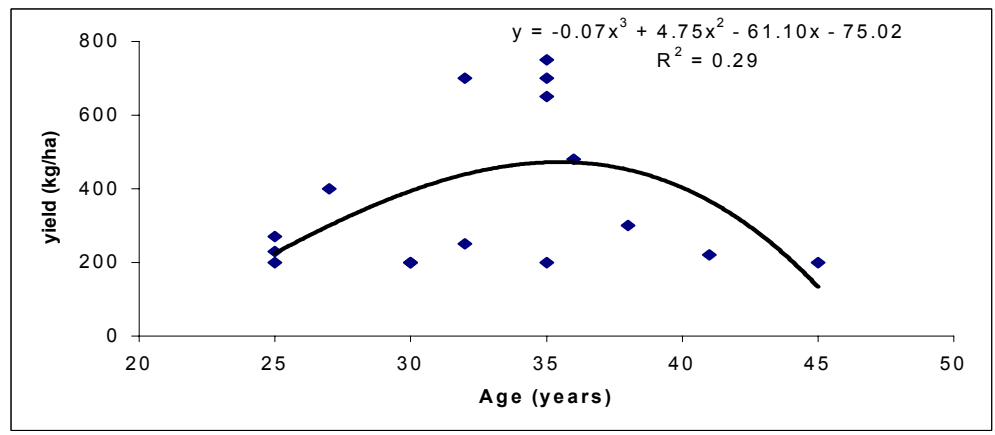

Figure 2: $\quad$ Relationship between yield and age of farm.

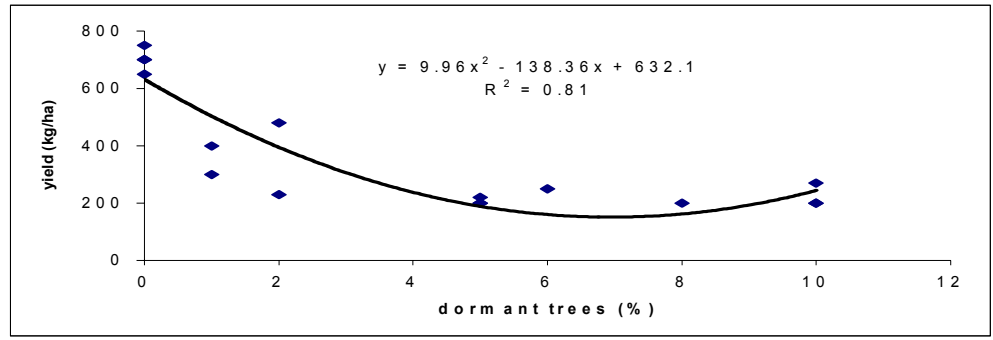

Figure 3: $\quad$ Relationship between yield and proportion of dormant trees.

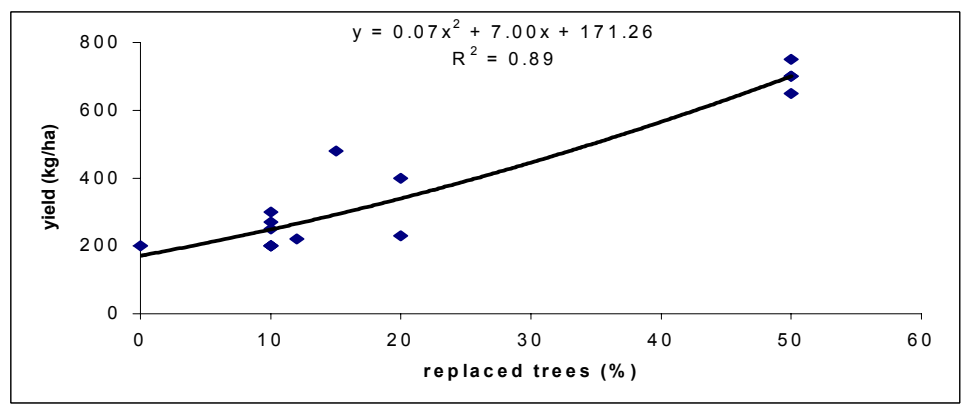

Figure 4: $\quad$ Relationship between yield and proportion of replaced trees. 
450 Geo-Environment and Landscape Evolution II

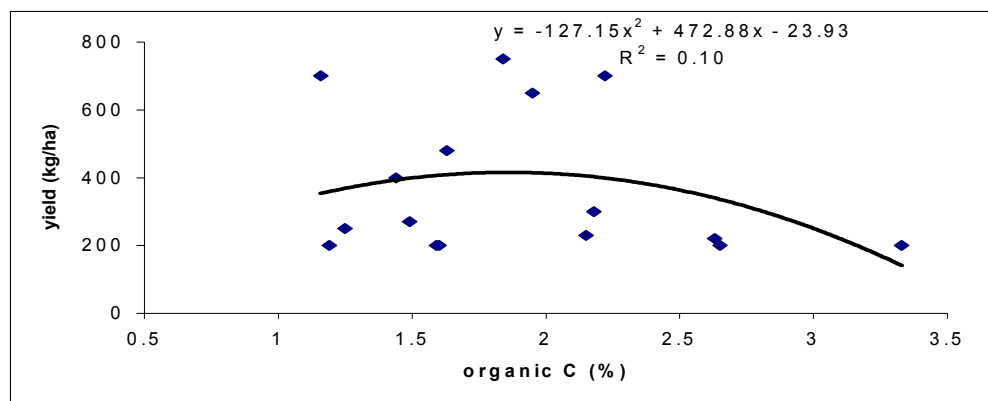

Figure 5: Relationship between yield and soil organic carbon.

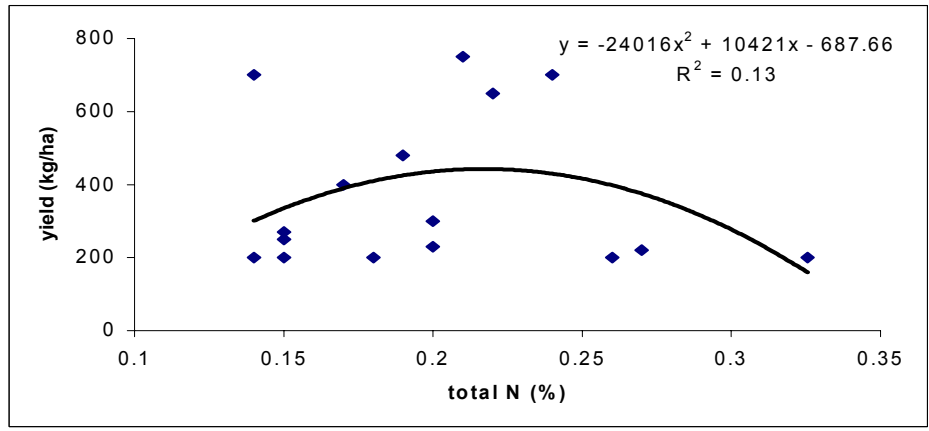

Figure 6: Relationship between yield and soil total nitrogen source.

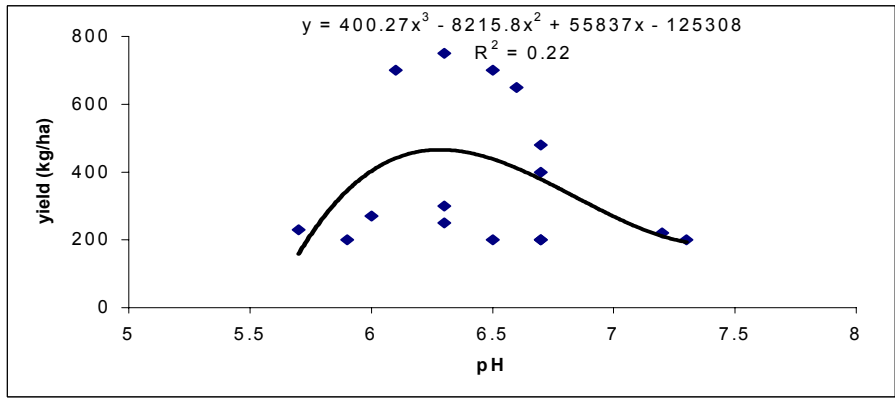

Figure 7: Relationship between yield and soil acidity.

Thus proper monitoring of acidity in the soils is crucial. Relationships between some soil variables are presented in Figures 8 and 9. Figure 8 shows the tendency of $\mathrm{pH}$ to increase with the organic $\mathrm{C}$ content of the soil. This has the potential to decrease yield (see Figure 5). The strong relationship between 
organic $\mathrm{C}$ and total $\mathrm{N}$ (figure 9) suggests that management of soil organic $\mathrm{C}$ is crucial to maintaining adequate levels of $\mathrm{N}$ in the soil.

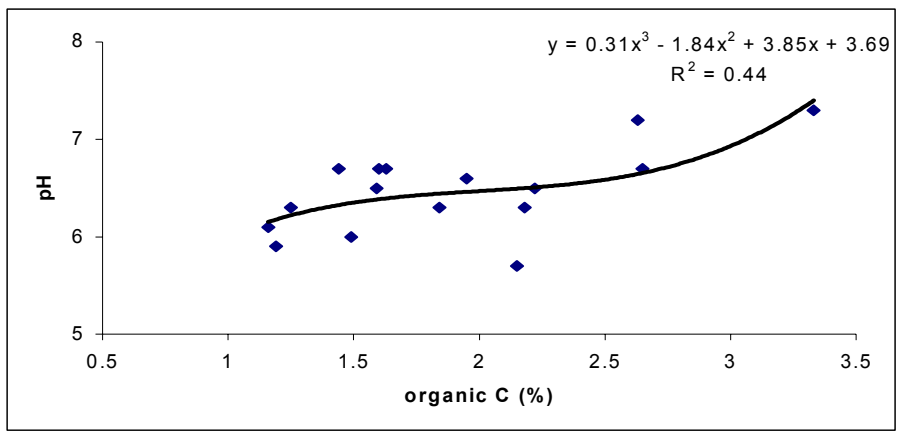

Figure 8: $\quad$ Relationship between $\mathrm{pH}$ and organic carbon.

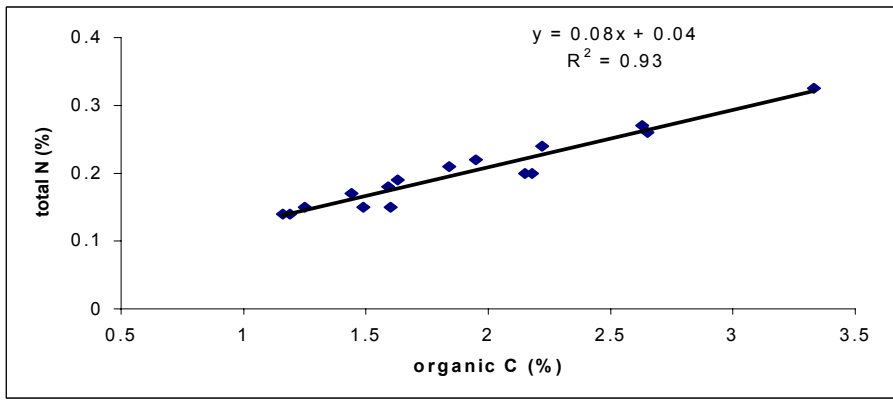

Figure 9: $\quad$ Relationship between total $\mathrm{N}$ and Organic C.

\subsection{Effects of biophysical and management variables on crop yield}

Linear multiple regression was used to relate crop yield to biophysical and socioeconomic data. Owing to high level of multicollinearity, independent variables were reduced to six. Among the variables in the model, two (Organic $\mathrm{C}$ and Age of farm) are negatively related to cocoa yield, whereas other variables are positively related to cocoa yield. However, soil variables are not significant to the model $(\mathrm{p}>0.05)$, whereas three management variables (plant density, proportion of dormant plants replaced and crop variety) are significant $(p<0.1)$. All the variables explain $97 \%$ of the variability of yield and the model can be used to predict yield at $99 \%$ confidence level. Figure 10 further shows the relative importance of the variables as measured by the standardized $\beta$ coefficients. Proportion of dormant plants replaced is the most significant management variable affecting yield, followed by crop variety (that is, $\mathrm{F}_{3}$ Amazon). 


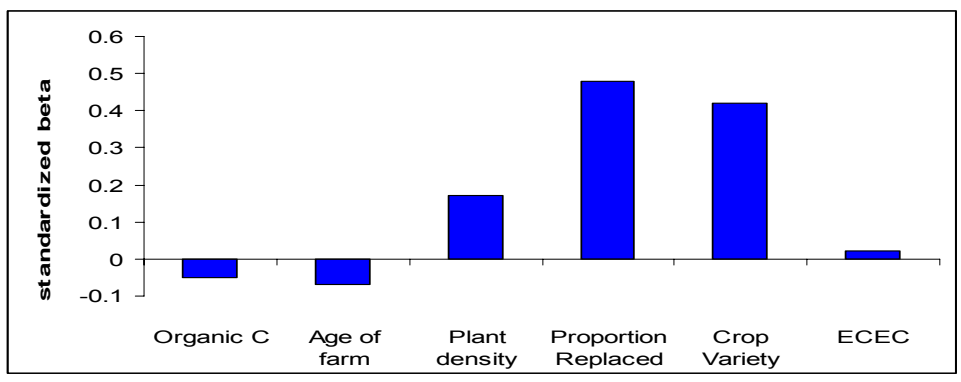

Figure 10: Relative importance of variables in the multiple regression model.

\section{Conclusions and recommendation}

Seventy percent of the cocoa farmers in the study areas are more than 60 years of age and over $50 \%$ of the farms are older than 45 years. More than half of the farmers are illiterates who keep no management records. Furthermore, yields on over $50 \%$ percent of the farms are below $300 \mathrm{~kg} / \mathrm{ha}$. These figures pointedly show a relationship between old age of farmers / farms and poor yield on the one hand and poor or no education on the other. The world market is increasingly flooded with average or low quality cocoa from new hybrid varieties. As long as the market is flooded with relatively large amounts of cocoa, buyers are not forced to pay a premium for cocoa of whatever origin. To the contrary, they can enforce large discounts for lower quality. They are able to select and mix according to their needs, all at relatively low cost. On the other hand, a small producer experiencing severe problems to expand production, or quantity, will probably find it more attractive to concentrate on improving quality. Once the market tightens up, the potential quality premium can even be a valuable asset and provide a competitive advantage. Achieving this improvement in quality will however depend, in the first place, on the physical potential of the product. Farmers who apply chemical inputs, must consider the aspect of profit making and quality of cocoa due to chemical residues in the product, coupled with the problem of environmental pollution through chemicals. Farmers should be encouraged to practise conservation and rehabilitation agriculture. This involves all steps which negate the processes of degeneration on cocoa farms, for example through consequent replacement of dormant trees, control of tree population for effective ground cover, properly managed canopy, integrated management systems that utilise resistant cultivars and application practices that emphasise proper timing and effective use of fertilizers at lower application rates. This would help not only to improve yield but also has the advantages of profitability, product quality and environmental protection. Given the situation in the international market in and the natural limitations of the cocoa farmers in Nigeria, the development of a market niche for quality was suggested. Further research will need to find out whether new breed varieties have the physical potential to achieve the said improvement in quality. The traditional Amelonado 
cocoa has been proved to be superior in every physical aspect (shell content, nib yield, fat yield and moisture content) when compared to beans derived from other varieties. The Amazon variety which is now very common in Nigeria, in addition to the suitable cocoa flavour characteristics, are more resistant to diseases in the environment and give better yields.

\section{References}

[1] Rehm, S. \& Epsig, G., The Cultivated Plants of the Tropics and Subtropics, Verlag - Josef Magraf: Germany, 1991

[2] Amusan, O.A., Amusan, F.O., Braimoh, K.A. \& Oguntunde, P.G., Quality Management Practices in Cocoa Production in South - Western Nigeria: Deutscher Tropentag 2005, ID-29 Online. www.tropentag.de

[3] Adegbola, M.O.K., Rehabilitating cocoa swollen shoot virus infected Cocoa Farms- the Offa-Igbo experience. Proc. $5^{\text {th }}$ Int. cocoa Res. Conf. Ibadan, Nigeria 1975: 182-8, 1977

[4] Adenikinju, S.A., E.B. Esan and A.A. Adeyemi, Nursery Techniques, Propagation and Management of Cacao, Kola, Coffee, Cashew and Tea Progress in Tree Crop research (Second Edition) A Commemorative Book to mark the $25^{\text {th }}$ Anniversary of CRIN, 1989

[5] Ajayi and Okoruwa Managing Uncertainties and Risks in Cocoa Production and Marketing in Nigeria, 1996

[6] Anon., Technical Consultation on Agricultural Methods and Techniques for Cocoa. Report of a meeting held in Itabuna, Bahia, Brazil. Cocoa Producers Alliance: Lagos, 1977

[7] Are, L., Methods of rehabilitating cocoa farms in Nigeria. Proc. $2^{\text {nd }}$ Int. Cocoa Res. Conf. Salvador, Brazil 1967: 383-7, 1969a

[8] Atanda, O.A. T. Quarcoo and M.O. Osundolire, Nursery techniques for tree crops in Nigeria. In Progress in tree Crop Research in Nigeria. A commemorative book, CRIN, 96-104, 1977

[9] Baiden, E. and A. Asare-Nyako (1986) Report of the Cacao Research Institute of Ghana 1982/83-1983/84, 205, 1986

[10] Odegbaro, O.A., Prospects of rehabilitating Amelonado cocoa with improved cocoa varieties in Nigeria without complete planting. Proc. $5^{\text {th }}$ Int. Cocoa Res. Conf. Ibadan, Nigeria 1975: 259-64, 1977

[11] Cocoa/Chocolate and Confectionary Alliance. Cocoa beans: Chocolate Manufacturers quality requirements. The Cocoa, Chocolate and Confectionary Alliance, 11 Green Street, London, $3^{\text {rd }}$ Ed. Jan. 1984. 19pp, 1984

[12] Prior, C., Cocoa replanting practices and the possible dangers from rootrots. Cocoa Industry Board of Papua New Guinea Newsletter 1, 2, 1981 